\title{
ANÁLISES E REFLEXÕES SOBRE METODOLOGIAS EDUCACIONAIS APLICADAS EM SALAS DE AULAS REMOTAS.
}

Semana Online Científica de Educação, 1a edição, de 25/10/2021 a 27/10/2021

ISBN dos Anais: 978-65-81152-18-5

(UNIB); Carlos Batista - Mestrando em Educação ${ }^{1}$

\section{RESUMO}

Ministrar conteúdos em salas de aulas virtuais se tornou uma prática necessária nos últimos tempos em vista de todo contexto pandêmico vivenciado. Com este cenário educacional adverso, novas práticas metodológicas surgiram e novas análises. O presente estudo visa esmiuçar essas questões detalhando algumas reflexões com base em resultados coletados. Para isso utilizou-se um período de análise de dados de 6 (seis) meses, entre Janeiro e Junho de 2021, vivenciados em 3 (três) centros de ensino, todos situados na cidade de São Paulo (SP), com alunos graduandos de cursos superiores nas áreas de Tecnologia. O objetivo é analisar práticas tecnológicas em salas de aulas remotas, suas abordagens, metodologias e consequências, primeiramente com os discentes e posteriormente com os docentes. O método de abordagem qualitativa utilizado foi da análise das aulas semanais durante o período estipulado, todas com duração média de 60 minutos. Os resultados compreendidos envolvem uma necessidade de se inovar nas abordagens, das apresentações dos conteúdos, com novas interações verbais e visuais. Entende-se que simplesmente transmutar o modelo expositivo de ideias de uma sala de aula física para uma sala de aula virtual se mostrou inadequado e pouco eficaz. Ao contrário de um estereótipo tradicional em que os meios digitais possibilitam o uso e a aplicação de infindáveis ferramentas, percebe-se que transcorre à obrigação imperativa de treinamentos constantes por parte dos docentes para manipulá-las. Desta forma conclui-se pelas análises feitas que ainda existe um modelo tradicional para exposição de conceitos. Observou-se que na medida que se inovava em uma apresentação remota, os resultados pedagógicos também eram revistos, para melhor. Se faz necessário, com isso, adotar novas práticas para que uma sala de aula virtual não seja apenas um momento de apresentação de debates on-line, mas sim um salutar período que transpassará suas qualidades para o ensino híbrido póspandêmico que vivenciamos.

PALAVRAS-CHAVE: sala de aula, ensino remoto, docente, discente 